\title{
Crystallisation of Social Dimension of Recognition (in Axel Honneth's Intentions)
}

\author{
Martin Solík \\ Doctor of Philosophy, Department of Legal Sciences and Humanities, Faculty of Mass Media Communication \\ University of Ss. Cyril and Methodius in Trnava, Námestie J. Herdu, 2, 91701 Trnava, Slovakia, Email: martinsolik@gmail.com
}

\author{
Doi:10.5901/mjss.2016.v7n1p538
}

\begin{abstract}
Lately the issue of social recognition has been discussed frequently - by philosophers, social scientists, politicians and scholars focusing on various fields, e.g. media theorists, sociologists, ethicists. The idea of recognition is in the centre of our attention mainly in the context of serious problems, which are related to migration of culturally diverse people; these aspects are, in fact, at the heart of the problem of recognition as such. The last decades have brought advanced communication technologies and new trends associated with communication between people from different cultures and minorities; however, the present situation forces us to face increasingly escalated conflicts, terrorist attacks and military operations. The questions of recognition, in their full complexity, have been a part of western thinking - even though not in its very centre - for several decades. The first part of the article mainly deals with the issue of social dimension of different forms of recognition proposed by Axel Honneth; emphasis is put on the third form of Honneth's recognition tripartite - solidarity. The second part of the text addresses the problem of social injustice. Social movements presume that they are able to establish new normative goals. The struggle for moral recognition is, however, motivated by experience of expected abuse, and functions as the very source of moral development. Various types of injustice share their essential basis - misrecognition. Perfect society is therefore a society built upon subjects that offer mutual recognition; members of such a perfect society expect that the social establishment should offer them certain possibilities of self-realisation.
\end{abstract}

Keywords: social recognition, Axel Honneth, solidarity, social injustice, social justice

\section{Introduction}

Axel Honneth follows the tradition of social and political theory, which claims to defend the modern project of enlightenment; he approves of procedural rationality, and sees it as a result of connection between rational procedures and empirical, normative reality of the living world. This space offers a rational organisation as well as creation of a specific normative leadership. Honneth refuses to build upon the atomistic tradition of social and political theory that is based on Hobbes's view on the society. He sees the driving force of social development in the efforts to establish relationships with regard to mutual recognition. Such efforts are necessary parts of the processes of self-realisation, development, freedom and individual autonomy. The main idea of his recognition theory may be defined as a necessary exploration of the processes of creating individual identities; these are associated with striving for 'acquirement' of mutual recognition by subjects that interact with the individuals in question.

Honneth focuses on the analysis of development and specification of universal conditions of reproduction and integration in terms of the social life - these processes of setting and maintaining relationships based on mutual recognition are, in their nature, normative, and seem to function also as imperatives of social life (M. Solík \& J. Mináriková, 2014). The given normative content is an integrated part of both 'relationship to oneself' and relationships related to mutual recognition. It represents the necessity of maintaining one's own identity while engaging in social interaction (I. Jenča \& H. Zárubová, 2015). We are members of the society because of "the experience of mutual recognition, i.e. the consciousness associated with rights and responsibilities that are reciprocally distributed in the context of specific circumstances." (A. Honneth, 2002, p. 501).

Taking into account the post-metaphysical and formal conception of morality, Honneth works with the normative concept of modern, which respects liberal and post-structuralist perspectives of moral and political philosophy (M. Hrubec et al, 2012). Definition of general and necessary conditions should be abstract and formal - at least to the extent that allows the morality theory to 'get rid of' the suspicion of being just a generalisation of some specific interpretations of good life. The concept of formal morality thus represents determination of universal and necessary conditions of selfmaking, i.e. social conditions that allow an individual to complete the process of self-making by making autonomous decisions. Honneth favours the form of social organisation that does not restrict the individual self-making in any ways. 
This fact is very important since the author uses it as the basis for his own theory of equitable social organisation, which builds upon intersubjective understanding of individual development. Following Ch. Taylor (1995), Honneth argues that individual self-making presumes the absence of external and internal pressures and limitations and thus also presumes negative as well as positive freedom; this freedom is reachable by applying mutual recognition within the processes of interaction (M. Solík, 2014). Free self-making is based on the premise of confidence in one's own abilities and accomplishments (D. Petranová \& N. Vrabec, 2013); these factors have to be positively evaluated by the other interaction participants.

\section{Axel Honneth's Establishment of Social Recognition}

Honneth (1996) defines three different forms of mutual recognition - love, law and solidarity - in the intentions of intersubjectivist conception of subject proposed by G. H. Mead, who was a defender of the direct connection between various degrees of social recognition and specific practical relationships to one's own self. Honneth states that love, the first basic form of recognition, involves various kinds of friendship, relationships between parents and children as well as erotic relationships based on strong emotional commitment. This form of mutual recognition contributes to creation of basic individual self-confidence. Honneth sees self-confidence as a basis of forming self-respect and trust, as an essential precondition of socialisation. Although the relationship between parents and children is asymmetrical - children are hierarchically subordinate to parents - relationships between parents are symmetrical. This symmetry seems to be, practically speaking, quite problematic since it depends on cultural environment. Such kind of recognition requires attitude that involves a higher level of empathy. However, love as a form of recognition does not include any cognitive character.

According to Honneth, the second form of recognition is defined as law - our mutual recognition defines us as the subjects of rights and responsibilities related to functioning society. We are bearers of a specific kind of common awareness of the norms which regulate identical rights and responsibilities enforced in a specific society. The basic premise of this conception is related to seeing oneself and other individuals as subjects that possess universal human rights and ability to act and make own moral decisions. This form of recognition serves as a basis for establishing a practical relationship with one's own intrinsic perception - self-respect. Self-respect allows man to see himself as someone who shares the ability to function as a morally responsible actor who is able to interact with other members of the community. Unlike recognition relationships related to primary social ties, legal relationship allows us to generalise recognition.

The third form of mutual recognition results from participating in the activities of human society and contributing to the ways of life which build on positive evaluation of all individuals. It is a type of social appreciation of specific features and abilities of individual personalities (M. Solík, 2015). "Honneth, like Taylor, points out that this form of recognition may be achieved only within the communities, which mutually share specific substantial values and respect the irreplaceable significance of all individuals and their importance for other people's lives." (Z. Palovičová, 2007, p. 660). This kind of mutual recognition results in practical relationship with oneself that may be defined as self-esteem. In contrast with the environment that generates the second type of mutual recognition (law), the values and goals of this community are different from the values and goals of other social groups. The aim here is not related to any universal recognition of equal statuses as in case of law; this kind of recognition rather indicates solidarity in terms of a particular community. Furthermore, self-esteem is not associated with anonymity and irreplaceability of individuals of the same kind - this approach is, once again, typical for the subjects of legal relationships. On the contrary, the issue of self-esteem involves feelings of uniqueness and irreplaceability of oneself as a person who contributes to mutual value horizon, collective identity and common projects. However, this kind of self-understanding cannot be based on a set of trivial or negative characteristics. The element, which differentiates a human being from other people, has to represent something valuable from the perspective of others (H. Pravdová \& J. Radošinská, 2013). These forms of recognition are mediated through mutual dialogic relationships with another person and do not include impersonal legal norms (J. Višňovský, J. Radošinská \& A. Predmerská, 2015). They are, in fact, associated with cultural and value framework of the society (J. Radošinská \& J. Višňovský, 2013), i.e. with the forms of collective identity that allow us to evaluate the extent to which specific members of the given society contribute to achievement and development of human values (H. Pravdová, 2009).

Human form of life depends on intersubjective recognition. The society practices so-called institutional recognition - Honneth refuses to associate this recognition with anthropological theories of personality. In his opinion, the basis for evaluation of the specific intersubjective nature of man lies in applying the adequate - the most developed - degree of recognition spheres (O. Roubal, 2011). In accordance with his remarks, the practical relationship between man and his own self, i.e. the ability to reflexively assure oneself in terms of intrinsic competencies and rights provided by recognition, is not established once and for all. Just like in case of subjective expectations related to recognition, this ability grows 
hand in hand with a number of spheres that have been identified and differentiated through social development in order to provide the specific parts of human personality (S. Gálik, 2012) with appropriate social recognition.

The second necessary degree of recognition, which helps man become a self-confident human being and allows him to achieve self-realisation, is (as shown by the above-mentioned forms of recognition) legal recognition. All premodern societies linked legal recognition of an individual human being to social evaluation, which was based on his origin, age, function. This evaluation also determined the extent of rights, which were legitimately available to that person or his/her family. Honour and social statuses were recognised by other members of the society. The mixture of legal respect and social recognition has become a basis of all traditional societies. However, it was later disrupted by emergence of bourgeois-capitalist societal establishment and related normative transformation of legal relationships; legal recognition distanced itself from the hierarchical value system. That is why all individual human beings possess the same extent of rights in the contemporary liberal society. The society has established an idea of individual performance based on paid work; validity of the previously accepted social 'status' classification principle (honour) has expired. The individual performance has, on the contrary, become a legitimate normative classification of credit. Legally speaking, all individuals possess equal respect, dignity and autonomy. Social evaluation has become directly associated with performance and solidarity (M. Hrubec \& M. Solík, 2015). However, the definition of 'performance' (what kind of activity, and to what extent, can be defined as 'performance') is based on background of the same value spectrum that is typical for economic life of the community - performance is therefore closely linked to the economic activity. Work is socially useful and men are able to, considering their physical constitution, work harder than women. Once again, we find ourselves discussing the institutional framework. Resources are being distributed and this massive process of transformation implies establishment of three different forms of social relationship that allow the members of the society to achieve mutual recognition - in many different forms, influenced by many particular rules. Regarding the new individual relationship to oneself, subjects have started to learn how to accept this 'me with myself' relationship - within intimate relationships, legal relationships and social relationships. These relationships have become dominated by the principle of solidarity. Solidarity teaches us to 'understand each other' in terms of being the subjects who possess particular abilities, talents and social value. This type of expansion of recognition spheres results in the chance for increase in individuality. Each and every new sphere of mutual recognition allows us to uncover and explore another aspect of the human subjectivity, which may be 'intersubjectively added' to the individual 'lists'.

According to Honneth, the spheres of recognition represent normative patterns of interaction that articulate the intersubjective human nature; moreover, they do so in a way which may result in a certain generalisation. The forms of mutual recognition describe socially established interactions and relationships which are, in their nature, normative and included in the norms of reciprocal recognition. However, family life has to - necessarily -involve also the legal respect to ensure that love would not be the only principle applied here. Honneth insists that social recognition is very valuable for the society itself - its value lies in creation and formation of social arrangements, which guarantee individual members of the society at least minimal social status. Performance and solidarity have become the key criterion of social recognition. This fact may suggest that performance and solidarity function as ideological elements and parts of the value horizon of capitalist reproduction. The criteria of performance and solidarity also provide reasonable distribution of resources and their highest aspiration is associated with intellectual prowess in context of a specific activity. Honneth strongly criticises various naturalist ideas; these portray a certain framework of collective features, suggesting that housekeeping, performed (mostly) by women, or childcare (again, often limited to women, mothers) are not socially valuable and thus are not worthy of social recognition. This perspective defines men as more productive - physically as well as intellectually. The given kind of naturalism is, according to Honneth's argumentation, distortive. It is rather a part of mistakes, which have always accompanied the social development and currently complicate recognition processes.

Honneth (1996, p. 128) uses the term "state of societal solidarity" in order to define a cultural climate that would allow members of a society to achieve full self-realisation. The state of societal solidarity is achieved when every member of the society is able to achieve self-esteem. He refuses to unite solidarity with feelings of sympathy or tolerance. Various ways of life and values cannot be deemed important only on the basis of tolerance that would not reject them. Solidarity brings the possibility of recognising other ways of life as able to provide something important and unique. The sphere of law is applied universally, while solidarity puts emphasis on the elements of uniqueness.

Recognition enables us to secure steady socialisation and simpler social integration of individuals. The second and third forms of recognition - unlike the first, constant one (thanks to which we may gain self-confidence), go through social development. Departure from traditional society to modern society, and therefore also differentiation of the forms of recognition, is realised simultaneously in various spheres. Complexity of the related procedures and norms has increasing tendency and contributes to creation of common political and moral will of individuals by deepening their moral responsibility. The reason of this deepening lies in the growth of the amount of persons who possess the universal rights; 
the extent of abilities, necessary for use and practical implementation of these rights, expands accordingly (A. Honneth, 2002). This expansion of post-conventional elements is changing and naturally weakening the traditional ethical life of community and value orientation of its members, heading towards higher levels of equality within the community members in terms of solidarity. The process of individualisation of this form of recognition means that individuals cease to sense the achieved self-esteem and rather start to consider themselves as recipients of the recognition type in question this process does not automatically imply any constraints related to emergence of solidarity since solidarity is, in its nature, dependent on the feeling of self-esteem related to individual community members.

Three forms of recognition outlined above may be seen as a schematic analysis of development of individual identity and also identify those forms of social development that would be the most suitable in terms of human psychological development, including dynamics and origin of social conflicts - this means that it is equally necessary to focus our attention on analyses of social tension and deprivation, phenomena that result from misrecognition of individual normative expectations and function as the driving force of social development (A. Honneth, 1992). The first form of misrecognition, which is also the exact opposite to the first type of reciprocal recognition and the most extreme kind of misrecognition, is associated with loss of human physical integrity, physical humiliation (abuse) or violation. A subject loses the opportunity to freely control own body and is exposed to physical or emotional violence - his/her basic selfconfidence and trust in the world around us is violated permanently. As a result, trust related to interaction with other subjects is disrupted too; positive image of oneself goes through serious disintegration. The second form of violating the normative relationship with oneself is associated with denial of certain rights, which are normally guaranteed by the society. Such personal misrecognition implies situations that result in violation or denial of certain fundamental or elemental rights by the society directly, although all legitimate members of the society possess these rights and thus demand them. The third type of misrecognition of normative expectations is a situation, in which social evaluation of an individual person or group is degraded and disgraced, i.e. individual or collective ways of life are dishonoured and defamed. This form of misrecognition may manifest itself through attacking a certain lifestyle, social status or cultural pattern. Results of such misrecognition are reflected in self-making and (dis)ability to sense the social value attributed to one's own skills. Own way of life ceases to imply positive meaning within the community and the person concerned loses self-esteem, i.e. opportunity to see oneself as a person who possesses abilities and characteristics that are worthy of respect and recognition.

Honneth integrates the theory of recognition and misrecognition with social conflicts and thus also with social dynamics, staying in intentions of normatively-critical dimension. Structures of today's ordinary life involve the obvious efforts to establish reciprocity in terms of all recognition relationships. Honneth's opinions point out to the direct link between social conflicts and moral dimension of their motivational framework. For instance, a political protest does not have to be a result of economic lack; it may as well result from an individual's feelings indicating that his/her claims associated with personal integrity, autonomy and status recognition have not been fulfilled in accordance with the immanent normative social order. Honneth is therefore looking for connections between violation of normative expectations and practical, cognitively confirmed form of social defiance. Each experience related to misrecognition and refusal of normative expectations may become a basis for social conflicts.

\section{Social Injustice}

Critical theory of society has been referring to the social phenomenon for years, considering also the influence of moral dissatisfaction. We talk about diffusion of groups, which intend to exercise their rights. Such groups are, in principle, always social movements. Even though we often claim that these movements tend to turn away from the purely material values, they are rather linked to the repeatedly mentioned politics of identity. According to Honneth, cultural minorities increasingly fight for recognition of their common value bases. Analysing the origin and content of social conflicts and movements, Honneth avoids the theory of revolutionary consciousness or psychological as well as physical needs of human beings. He does not intend to formulate a theory of revolutionary struggles and social changes. His analysis is based on the recognition theory and tries to conceptually unify the nature of emergence and behaviour of social movements as such.

Social movements claim to reveal the secrets of morality and moral dissatisfaction, trying to solve the problems of the society through their own problem. If these problems existed, emancipation would not be necessary and there would not be any reason to fight for dignity. The belief that social movements are able to establish new normative goals seems to be prevailing. These movements often only confirm the political and moral conflicts that resonate in the society and are labelled as the dissatisfied, those who possess insufficient rights. Many topics are perceived as acute but they do not reach the dimension of becoming a society-wide problem since the society filters several problems related to denying 
rights and does not allow them to 'reach the surface'. Honneth warns against hasty adaptation of normative terminology because of the political goals determined through selection, which is influenced by moods in a specific timeframe. "The factors that, in terms of the framework of critical societal theory, primarily hold our attention are related to a large number of politically organised efforts of cultural groups to achieve social recognition of their own value convictions and lifestyles." (N. Fraser \& A. Honneth, 2004, p. 154). The Western culture is watching women's movements, ethnic minorities, and sexual minorities gain intensity in order to fight against misrecognition and marginal approach, which is rooted in the institutionalised composition of values. These values or rather idealised visions are adapted to the idea of a heterosexual white male who was brought up in the light of either Christianity or Judaism, i.e. within traditions of the most widespread religions in the Western culture. The aim of emancipation movements is to change culture of the majority by overcoming stereotypes and characteristics. This is permissible in countries where the politics of identity resonates, but governments, being purely pragmatic, primarily focus on the problems of labour policy, social welfare, ecology; the politics of identity thus assumes only inferior status. Countries, which turn their attention to social issues, e.g. Germany or France, are mostly the countries of 'the old continent'.

Honneth notes typical forms of socially caused failures. These deficiencies are mostly social. We may encounter single mothers with low qualifications; long-term unemployment and related social isolation and sometimes even breakdown in privacy; dishonouring access to job performances of today's people in their fifties, who were once needed and appreciated but currently, in accordance with 'progress' in their industries, become redundant - even though their performance and experience often reach notably higher levels than in case of today's people in their twenties; agriculture operates with so-called 'hard work', and yet its profit balances on the edge of difficult sustainability or even unsustainability of the sector; many families with children constantly go through serious financial struggles. These social problems are very real and open the way to 'social battlefield' where social movements are clamouring for recognition. Highly developed societies encounter growing tendency of cultural communities to fight for recognition of their collective identities. We talk about a 'summary' of feelings, conflicts and identities that can be shared and, conversely, about those, which are excluded from the process. According to Albert O. Hirschman (1995), it is important to realise the threat of social conflicts, treatment of which cannot count on any normative consent of all members of the society.

Charles Taylor emphasises that the history of liberal capitalist society has always been accompanied by the struggle for legal equality, whereas today the struggle is replaced by social groups, which are demanding recognition of their culturally defined difference (M. Solík, 2010). Honneth criticises Taylor's use of too narrow notion of legal recognition; applying this approach, Taylor schematically eliminates the issue and sees it as a kind of homogenising, equal treatment (M. Solík, 2014).

Honneth, rather than Taylor, turns his attention to legal equality and becomes active in the context of the processes of reclaiming social recognition of individual value systems and life forms. "As well as the today's movements related to politics of identity cannot be reduced to the idea of establishing cultural goals, the traditional resistance movements of the late $19^{\text {th }}$ and early $20^{\text {th }}$ centuries cannot be associated only with material or legal objectives." (N. Fraser \& A. Honneth, 2004, p. 161). Many illegitimate means of social exclusion and suppression (such illegitimate means of eliminating and suppressing can be found in racism and nationalism) also seem to be closely connected to the politics of identity.

Honneth notes that the legislative focus of the critical societal theory on the publicly perceptible demands of social movements leads to a result that was not intended, i.e. to an adoption of politically preferred views. He sees the idea of the politics of identity as a sociological artefact and justifies conceptualisation that is used in terms of the issue of recognition rather independently, without any direct relation to social movements. He presumes that transformation of the basic concepts of the critical societal theory can be - taking into account terminology of the theory of recognition - seen as justified thanks to better understanding of the motivating sources of social dissatisfaction and social resistance rather than on the basis of assumptions related to politics of identity and multiculturalism objectives. In other words, Honneth's turn to the theory of recognition is an attempt to address some immanent theoretical problems; it is therefore not a response to the contemporary social trends. Placing emphasis on this systematic differentiation, he is trying to show that the questions of distributive justice may be better illustrated by using the normative categories that are related to a sufficiently differentiated theory of recognition. He also claims that, eventually, the problem of normative justification of the critical societal theory as a whole will not be able to remain intact either.

It is necessary to urgently ask what kinds of conceptual means do exist and may help the social theory decide what phenomena (and to what extent) the subjects of social reality perceive as social injustice. A definitive answer cannot be expected to appear any time soon. The discourse works with the basic terms, which serve as a kind of enlightenment. We tend to express many social expectations that will remain unfulfilled. New versions of critical societal theory tend to favour the belief that the objectives, set by social movements, adequately inform us about the forms of social injustice. Other 
dimensions of discontent are appearing rather in terms of theoretical speculations (which, instead of dealing with empirical indicators, focus mostly on sociological considerations). Addressing this issue, Honneth refers to A. Gramsci's inclination to anti-normativism, i.e. respects the idea of forbidding the preliminary normative expectations of the subjects in relation to the society; these normative expectations tend to commonly place the aspects, which should serve as a socio-theoretical premise, outside the centre of our attention.

We become aware of social injustice at the moment when we cannot rationally understand it on the basis of generally acceptable reasons. How can any institutionalised arrangement count on agreement? This assumption may, indeed, take into account the fact that individual evaluation of social processes will imply a certain formal structure, which cannot be completely independent from the structure of public practices associated with apologising - if any argument that is hardly deniable becomes universally justified, it will later be applied and will affect the subjective view. On the other hand, such restrictions related to forms of reasoning completely lose the dimension of normative aspects. An individual notices the normative aspects in order to know how far he/she can go with the established principles.

As we have noted above, subjects express their normative expectations of the society. The problem here is to be sufficiently abstract in order to cover the largest possible number of different claims and demands and, if possible, give them a solid normative basis. The last forty years have shown that the subjects mostly expect the society to recognise their claims associated with identity. Social disruption of one's own integrity, honour or dignity represents the normative core of lawlessness. Subjects define the institutionalised procedures as social injustice when they see that these procedures misrecognise the aspects of their personalities, which they consider to be worthy of recognition.

The conception of recognition has not earned its crucial importance only because of articulating the objectives of a new type of social movement, but rather because it has proven to be an appropriate way of categorical detecting of social injustice in all its diversity. The reasons why we focus on normative terminology related to the theory of recognition may be seen in the accumulated results of examination of the moral resources, in which the society finds a fertile ground for realisation of its own social discontent.

It is necessary to take the first step and try to understand the moral order in society as a fragile mechanism which depends on various degrees of recognition relationships. Then we will take the second step - to show the extent to which the established order of recognition may eliminate social conflicts stemming from the moral experience of unjust misrecognition. Honneth's argumentation is based on abstraction from anthropological categories.

\section{Social Justice and Normative Theory of Recognition}

The concept of recognition, in case of Honneth's argumentation, has a wider dimension - he does not aim to use it only for cultural minorities, subsuming here also the conflicts arising from relocation. Honneth finds solutions to these issues in the politics of identity, which is the beginning of public recognition of collective identities; the need for public recognition of collective identities brings us to culture and its role in social conflicts. Honneth asks himself whether the requirements of public recognition of collective identities may be fulfilled through application of the principle of legal equality. In the past decades homosexuals and the people with disabilities used to be defined in terms of sexual or biological deviations. Today they are characterised as culturally integrated communities with common language and shared perceptions (W. Kymlicka, 1998). Building upon this construction of cultural identity, socially discriminated groups have created selfunderstanding, which now enables them to see themselves fighting almost on the same front as ethnic groups that fight for respect; for their sovereignty (N. Fraser \& A. Honneth, 2004, p. 211). Entire communities have defined themselves through collective identities and these "constructed" collectives now struggle for recognition of their culturally defined sovereignty. Collectively articulated requirements related to recognition should improve the position of individual group members within the cultural identity. It turns out that these are fundamental individual rights, which are denied to them as members of a specific group; the social discrimination associated with misrecognition thus has to be eliminated. According to Honneth, demands of the politics of identity are linked to the normative framework of the struggle for equal legal treatment and seek to eliminate injustice resulting from inequalities and unequal treatment in comparison with the majority. Social groups' demands related to recognition of their cultural identity require resources and arrangements; these allow them to develop feelings of companionship within their communities. They are trying to stick to their way of life and gain economic means in order to preserve it, pointing out to legal equality as well as past and present social disadvantages. The aim here is to achieve governmental removal of the obstacles that have placed a social group in an unfavourable position, especially in comparison with the majority culture.

Honneth formulates/demands recognition of social group by the majority culture. From this point of view, recognition does not play only a limited role that aims to ensure the continued existence of the communities; the acceptance of goals and value orientations is also very important. The transition from tolerance to recognition, i.e. the 
transition from tendency 'to ignore the differences' to 'observing them', may be defined clearly here. Pretension of the same rights (as well as political rights) remains intact and is integrated with willingness to recognise specific values.

Cultural minorities should be treated respectfully, without any degradation. Feminist organizations advocate against pornography which represents women disgracefully. This humiliation creates a disadvantage. Addressing this issue, Honneth argues that violation of dignity is not related to freedom. In case we exceed the requirements of decent approach to our own values and goals, we are able to disrupt the legal framework of the principle of equality. Cultural communities want to ensure the application of measurements that cannot be derived from equal treatment. Their vision is rooted in the belief that the society they live in should recognise their value (misrecognition is entirely unacceptable). That is why Honneth's theory constantly deals with the question of equal treatment. Therefore, it seems that cultural minorities will have a significantly greater chance to succeed if they choose to follow an alternative method of justifying their demands, through which they would strive for recognition of the value of their own culture - not by referring to the relevant principles of recognition, but rather independently, regardless of all institutionalised value considerations and thus, in this sense, absolutely. However, the meaning of this postulate remains, at least in terms of the current debate, unclear.

People articulate their normative expectations related to the society in order to achieve social recognition of their abilities - these abilities should be recognised by the others, i.e. variously generalised subjects. The content of this moral sociological fact, according to Honneth, may be developed in two different ways - the first one is associated with moral socialisation of the subjects, the other is related to moral integration of the society. Discussing the first dimension of moral socialisation, Honneth notes that subjects acquire socially standardised recognition responses within the processes of shaping individual identities. Each subject assumes two different positions at the same time, being a full member of the community and, simultaneously, a 'special' member of the community - this is also an affirmation of one's own 'special' abilities and needs that forms a full-fledged personality. Three spheres of reciprocal recognition involve defined moral infrastructures of social living world, in which people can be assured of their integrity and dignity. We are dependent on the environment of social forms of interaction that are organised by the normative principles of mutual recognition. If these principles of recognition are absent, the subject becomes humiliated and misrecognised - as a result, there are many harmful consequences that negatively influence the formation of human identity and restrict the chances of selfrealisation (Z. Palovičová, 2007, pp. 662-663). If we take into account the society members' viewpoint, the society may be discussed as a legitimately organised structure only in case it is able to provide (at different levels) the appropriate conditions for reciprocal recognition while developing personal identity together with individual self-realisation.

Honneth (1996, p. 171) argues that moral consideration is, in the traditional sense, too narrow to be able to take into account all aspects of undisturbed creation of an individual. According to Palovičová (2007, p. 663), Honneth shows that legal recognition is just one of the possible ways of achieving recognition, "which should enable good or fulfilled life. However, morality as an institute defending human dignity should include two other equivalent principles - the principle of necessity and the principle of merit." Honneth's criticism on Rawls's conception and Ch. Larmore's political liberalism as well as his critical distance towards Habermas are based on this particular perspective. Honneth criticises them since they seem to marginalise the goals (e.g. enforcement of social recognition for own value systems) and thus focus primarily on legal equality. Honneth's theory of recognition is considered to be principally opposite to procedural understanding of justice.

Morale of the society should cohere with quality of relationships recognition that is guaranteed by the society itself. Justice of the society is thus measurable through the extent to which it is able to guarantee the conditions of mutual recognition that help develop personal formation of identity and individual self-making. According to Honneth, demands of social integration may be understood through referring to the normative principles of political ethics only when they mirror social expectations of the 'socialised' subjects. Normative structural transformation of the society can be derived from the initiative related to the struggle for recognition. If the requirement of social recognition includes validity overlap that guarantees mobilisation of hardly traceable reasons and leads to increased quality of social integration, we can speak of moral progress. Normative principles strengthen and form social recognition. Recognition is therefore not an objective, but it is rather a prerequisite that enables man to develop a satisfactory relationship with oneself.

\section{Conclusions}

Honneth's thinking involves tendency to institutionalisation; he favours adaptation of political ethics and social morality to guaranteed relations of recognition. Justice and well-being of the society are measured by the degree of its ability to ensure the conditions for mutual recognition that allow shaping of personal identity and individual self-realisation to proceed sufficiently. 
Honneth, just like Rawls, underestimates negative effects of the current economic globalisation (M. Hrubec, 2011, p. 318). Fraser draws attention to globalisation's ability to influence national social, economic, political and cultural phenomena by a variety of interventions that can worsen national circumstances, e.g. standards of living, and thus may jeopardise national and international justice. Honneth's critical theory of recognition does not determine limits of liberal theories of international relations (M. Solík \& J. Mináriková, 2014). Guarantee of the basic universal rights and freedoms requires political responsibility, solidarity and identification with the political community. A certain kind of basic goodness, which manifests itself in the form of relationships related to mutual recognition, serves as guidance for identifying with the society (M. Hrubec, 2014). Unlike Rawls, Hegel does not presume that this fundamental goodness is good in the strict sense of the word, it is not something that should be divided and distributed according to equitable standard; it rather seems that Hegel seeks to defend the idea that the modern society can be fair only to the extent to which it is able to allow all subjects to equally participate in this common good; after all, Honneth himself confirms this statement through his argumentation (A. Honneth, 2000, p. 28). Rawls fully understands goodness in the context of distributive social justice but, on the other hand, he does not understand its inception in terms of the basic goodness, which is a precondition for any justice.

Fuller integration of relations depends on the depth of anchoring the individuals within relationships to others. This framework may be exceeded; we may express solidarity and identify ourselves with regional or continental intercultural communities as well as with the cosmopolitan community. This version is - sort of - the forgotten element of Hegelian philosophy, which functions as a basis for universalistic opinion of the community. Honneth follows Hegel's concept of recognition as well as the notion of community but does not offer any neo-Hegelian conception that would exceed the limits of international politics and analyse global and transnational issues. The considerable potential offered by Honneth's theory is therefore not used efficiently in terms of cosmopolitan theory. Honneth moves within the dimension which presumes living in the social order that allows all individuals to steadily develop their identities, legal equality and social recognition. His spheres of recognition determine what is to be perceived as fair and what is, on the contrary, unfair. At the same time, Honneth believes that 'valid' recognition spheres he proposes have their own validity overlap, through which the continuous struggles and problematic terminological conceptions of recognition are carried out. Morality has its own dialectic, which is constantly changing the angles that have not been taken into account yet.

\section{References}

Fraser, N., \& Honneth, A. (2004). Přerozdělování nebo uznání? Praha: Filosofia.

Gálik, S. (2012). Filozofia a médiá. K filozofickej reflexii vplyvu médií na utváranie (súčasnej) kultúry. Bratislava: IRIS.

Hirschman, A. O. (1995). Social Conflicts as Pillars of Democratic Market Societies. In A Propensity for Self-Subversion. Cambridge (Mass.).

Honneth, A. (1992). Integrity and disrespect: Principles of Conception of Morality Based on the Theory of Recognition. Political Theory, Vol. 20, No. 2, 187-201.

Honneth, A. (1996). The Struggle for Recognition: Moral Grammar of Social Conflicts. Cambridge, Massachusetts: The MIT Press.

Honneth, A. (2000). Suffering from Indeterminacy. An Attempt at a Reactualization of Hegel's Philosophy of Right. Amsterdam: Van Gorcum.

Honneth, A. (2002). Grounding Recognition: A Rejoinder to Critical Questions. Inquiry, Vol. 45, No. 4, 499-519.

Hrubec, M. et al. (2012). Etika sociálních konfliktů. Praha: Filosofia.

Hrubec, M. (2011). Od zneuznání ke spravedlnosti. Praha: Filosofia.

Hrubec, M. (2014). Preconditions of an Intercultural Communication. Communication Today, Vol. 5, No. 2, 33-49.

Hrubec, M., \& Solík, M. (2015). Global Conflicts and the Macro-regional Modernities. Communication Today, Vol. 6, No. 1, 83-98.

Jenča, l., \& Zárubová, H. (2015). Global village and the intercultural dialogue. European Journal of Science and Theology, Vol. 11, No. $6,25-35$.

Kymlicka, W. (1998). Finding Our Way: Rethinking Ethnocultural Relations in Canada. Toronto: Oxford University Press.

Palovičová, Z. (2007). Normatívnost' pojmu uznania. Filozofia, Vol. 62, No. 8, 658-667.

Petranová, D., \& Vrabec, N. (2013). Persuázia a médiá. Trnava: Univerzita sv. Cyrila a Metoda v Trnave, Fakulta masmediálnej komunikácie.

Pravdová, H., \& Radošinská, J. (2013). Media culture in the context of transformation of contemporary spiritual values and spirituality. European Journal of Science and Theology, Vol. 9, No. 6, 169-178.

Pravdová, H. (2009). Determinanty kreovania mediálnej kultúry. Trnava: Univerzita sv. Cyrila a Metoda v Trnave, Fakulta masmediálnej komunikácie.

Radošinská, J., \&Višňovský, J. (2013). Aktuálne trendy v mediálnej kultúre. Trnava: Univerzita sv. Cyrila a Metoda v Trnave, Fakulta masmediálnej komunikácie.

Roubal, O. (2011). Potíže s identitou - umění sebetvorby a problém uznání. Communication Today, Vol. 2, No. 1, 27-38.

Solík, M. (2010). Komunikácia v spoločenskom kontexte - uznanie ako intersubjektívny predpoklad. Communication Today, Vol. 1, No. 2 , 
41-57.

Solík, M. (2014). K problematike kultúrneho uznania Charlesa Taylora (Charles Taylor on the question of cultural recognition). Filosofický časopis, Vol. 62, №. 2, 203-216.

Solík, M., \& Mináriková, J. (2014). Social Recognition on a Global Scale: Opportunities and Limits of Media Reflection. Communication Today, Vol. 5, No. 2, 21-31.

Solík, M. (2015). Problém uznania a jeho ukotvenie. In M. Solík (Ed.), Rozpory a alternativy globálního kapitalismu (pp. 153-167). Praha: Filosofia.

Taylor, Ch. (1995). Omyl negativní svobody. Filosofický časopis, Vol. 43, No. 5, 795-814.

Višňovský, J., Radošinská, J., \& Predmerská, A. (2015). Digital journalism: rethinking journalistic practice in the era of digital media. . European Journal of Science and Theology, Vol. 11, No. 6, 57-66. 